\title{
Glucocorticoid receptor polymorphism in genetic hypertension
}

\section{J Kenyon, M Panarelli ${ }^{1}$, L Zagato $^{2}$, L Torielli ${ }^{3}$, R P Heeley ${ }^{4}$,

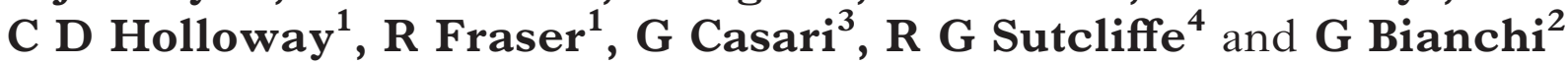

Molecular Medicine Centre, Western General Hospital, Edinburgh, UK

${ }^{1}$ MRC Blood Pressure Group, Western Infirmary, Glasgow, UK

${ }^{2}$ Department of Nephrology, S Raffaele Hospital, Milano, Italy

${ }^{3}$ PRASSIS-Sigma Tau Research Institute, Milano, Italy

${ }^{4}$ Division of Molecular Genetics, IBLS, University of Glasgow, Glasgow, UK

(Requests for offprints should be addressed to C J Kenyon, Molecular Medicine Centre, Western General Hospital, Edinburgh EH4 2XU, UK)

\begin{abstract}
The Milan hypertensive strain of rat (MHS) displays abnormalities in both renal function and adrenocortical activity. While the pressor role of the former has been studied in detail, the role of the latter has not yet been clearly evaluated. In the present study, glucocorticoid receptor (GR) binding characteristics in liver cytosol from adult MHS and Milan normotensive controls (MNS) have been investigated. Dexamethasone, aldosterone and corticosterone were bound with lower affinity to cytosol of MHS rats compared with that of MNS rats. This pattern of binding could explain the raised plasma corticosterone concentrations and adrenocortical hypertrophy previously noted in MHS.

The coding sequence of MHS and MNS GR genes have been determined. The MHS gene differed in four respects from that of MNS: three
\end{abstract}

silent point mutations and a polymorphic microsatellite region in exon 2. The latter polymorphism has been used in cosegregation studies of $\mathrm{F}_{2}$ hybrids of MHS $\times$ MNS. The MHS GR genotype was associated with hypercalciuria and lower blood pressure in female rats and lower body weight in male rats. Although the effect on blood pressure is small, it is consistent with the affinity data. MHS GR genotype cosegregated with lower blood pressure in $\mathrm{F}_{2}$ rats and displayed a lower affinity in binding studies.

In conclusion, GR polymorphism may be responsible for differences of adrenocortical function between MHS and MNS. This may lead to a reduction in the blood pressure difference between the two strains.

Fournal of Molecular Endocrinology (1998) 21, 41-50

\section{INTRODUCTION}

The Milan hypertensive strain of rat (MHS) presents altered renal function (Bianchi et al. 1986) and increased adrenocortical activity (Ferrari et al. 1985) when compared with its normotensive control strain (MNS). A significant portion of the MHS hypertension is sustained by the kidney (Bianchi et al. 1984) as demonstrated by a long series of observations, starting from studies of renal cross transplantation between the two strains (Bianchi et al. 1986). Recently, genetic studies have demonstrated that a point mutation within the $\alpha$-subunit of a heterodimeric cytoskeleton protein, adducin, increases $\mathrm{Na}^{+} / \mathrm{K}^{+}$ATPase activity when transfected into renal epithelial cells (Tripodi et al.
1996). This mutation also affects blood pressure, accounting for $40 \%$ of the difference in blood pressure between MHS and MNS, when interacting with a mutated $\beta$-adducin subunit (Bianchi et al. 1994).

The present study has considered whether the residual gap in blood pressure difference between MHS and MNS could be due to abnormal aspects of adrenocortical function. Previous studies have established that MHS exhibit adrenocortical hypertrophy with higher steroid secretory rates and raised plasma corticosterone concentrations compared with MNS (Stewart et al. 1993, Fraser et al. 1994, Ferrari et al. 1985). There are also signs of mineralocorticoid excess in MHS with extracellular volume expansion, plasma renin 
suppression and increased exchangeable body sodium content (Fraser et al. 1994). Taken together, these observations might suggest that the normal negative feedback regulation of corticosterone synthesis is reduced because hormone access to the glucocorticoid receptor (GR) is impaired. This in turn raises plasma corticosterone concentrations causing activation of mineralocorticoid receptors. Clinically similar situations arise because of defects in steroid metabolism or because of intrinsic abnormalities of the GR (Lamberts et al. 1992, Arai \& Chrousos 1994). Steroid metabolism has been shown to be different between MHS and MNS but not in a way which would impair corticosterone binding to adrenocorticosteroid receptors (Stewart et al. 1993). The present study has considered an alternative possibility, that GR function is affected. First, we have compared MHS and MNS glucocorticoid binding characteristics in liver cytosol extracts. Secondly, we have compared the sequences of cDNA for the GR genes of MHS and MNS. Thirdly, we have screened DNA from $\mathrm{F}_{2}$ hybrids of crosses of MNS and MHS to determine whether an expressed microsatellite marker in the GR gene shows association with blood pressure.

\section{MATERIALS AND METHODS}

\section{Animals}

Rats used in receptor binding studies and for GR gene sequencing were obtained from the Field Station, University of Sheffield, UK and were maintained at a constant temperature on a $12 \mathrm{~h}$ light: $12 \mathrm{~h}$ darkness cycle with free access to food and water. All $\mathrm{F}_{2}$ rats used for genetic analysis were bred in our own facilities in Milan and maintained as described elsewhere (Bianchi et al. 1994). $\mathrm{F}_{1}$ hybrids were produced by crossing MNS with MHS. No maternal or paternal effects were observed in average systolic blood pressures in $\mathrm{F}_{1}$ hybrids. By intercrossing $\mathrm{F}_{1}$ hybrids, an $\mathrm{F}_{2}$ population was obtained, consisting of equal numbers of offspring from each reciprocal cross (251 total individuals, 121 male and 130 female).

\section{GR binding}

On separate occasions, pairs of MHS and MNS rats (female: 200-250 g; male 300-350 g) were stunned and decapitated. Livers were perfused with ice-cold isotonic saline via the hepatic portal vein to remove residual blood. Once blanched, livers were excised and minced in three volumes of ice-cold buffer $(10 \mathrm{mM}$ Tris- $\mathrm{HCl}, 2 \mathrm{mM}$ dithiothreitol, $1.5 \mathrm{mM}$ EDTA, $0 \cdot 1 \mathrm{M}$ sodium molybdate, $10 \%$ glycerol) and homogenised using a Polytron homogeniser (Kinematic, Lucerne, Switzerland). The homogenate was centrifuged $(20000 \boldsymbol{g}, 20 \mathrm{~min})$ and the supernatant was centrifuged again $(105000 \boldsymbol{g}, 1 \mathrm{~h})$. Preparations were maintained at $<5{ }^{\circ} \mathrm{C}$ throughout. The protein content of the final supernatant was determined by the method of Lowry et al. (1951).

Binding constants for dexamethasone, corticosterone and aldosterone (Sigma Chemical Company, Poole, Dorset, UK) were calculated by measuring homologous and heterologous competition for $\left[{ }^{3} \mathrm{H}\right]$ dexamethasone binding sites. Aliquots of cytosol (final protein concentration $2 \mathrm{mg} / \mathrm{ml}$ ) were equilibrated overnight at $4{ }^{\circ} \mathrm{C}$ (except when investigating the effects of temperature) with $3 \mathrm{nM}[1,2,4-$ $\left.{ }^{3} \mathrm{H}\right]$ dexamethasone $(1.44 \mathrm{TBq} / \mathrm{mmol}$; Amersham International plc, Amersham, Bucks, UK) and various concentrations of non-radioactive ligand. Steroids were dissolved in ethanol at a concentration of $10 \mathrm{mM}$ and serially diluted with buffer to give appropriate final concentrations. The total volume of incubation was $0.25 \mathrm{ml}$. Non-specific binding was measured by incubating cytosol with a 500 -fold excess of non-radioactive dexamethasone. Free and bound fractions were separated by the addition of $0.25 \mathrm{ml}$ of a charcoal suspension $(5 \mathrm{~g}$ activated charcoal and $0.5 \mathrm{~g}$ Dextran T70/1 buffer). After vortexing and centrifuging $(1500 \mathrm{~g}, 10 \mathrm{~min})$, the supernatants were removed and their radioactivity counted. Dissociation constants $\left(K_{\mathrm{d}}\right)$ and binding capacity $\left(\mathrm{B}_{\max }\right)$ were calculated from heterologous competition curves with the curve fitting program, Ligand (Biosoft, Cambridge, UK), using information from equivalent homologous competition with dexamethasone.

The effects of temperature on receptor binding were assessed in two experiments. Receptor binding constants were estimated for dexamethasone after cytosol had been equilibrated at $37^{\circ} \mathrm{C}$ for 30,60 , and $120 \mathrm{~min}$ with radioactive and nonradioactive dexamethasone as described above. To investigate the thermostability of the bound $\left[{ }^{3} \mathrm{H}\right]$ dexamethasone-receptor complex, cytosol was equilibrated at $4{ }^{\circ} \mathrm{C}$ overnight with $\left[{ }^{3} \mathrm{H}\right]$ dexamethasone $( \pm 0.5 \mu \mathrm{M}$ non-radioactive dexamethasone) and then transferred to $24^{\circ} \mathrm{C}$ and $37^{\circ} \mathrm{C}$ waterbaths. Aliquots were removed at intervals for separation of free and bound radioactivity.

\section{GR genotype determination}

Genomic DNA from $\mathrm{F}_{2}$ rats was extracted from the tail according to a standard procedure (Laird et al. 1991). MNS and MHS GR microsatellites were amplified using a GeneAmp PCR System 9600 thermal cycler (Perkin-Elmer-Cetus, Norwalk, CT, 
USA) in a $20 \mu \mathrm{l}$ reaction volume. Genomic DNA $(250 \mathrm{ng})$ was combined with $10-20 \mathrm{pmol}$ of each primer and $1 \mathrm{U}$ Taq polymerase (Bioline, Glasgow, UK) in a mixture containing $2 \mathrm{mM} \mathrm{MgCl}, 67 \mathrm{mM}$ Tris- $\mathrm{HCl}(\mathrm{pH} \quad 8 \cdot 0), 16 \mathrm{mM} \quad\left(\mathrm{NH}_{4}\right)_{2} \mathrm{SO}_{4}, 0.01 \%$ Tween-20 and $125 \mu \mathrm{M}$ of each dNTP. Reactions were cycled 30 times at $94{ }^{\circ} \mathrm{C}$ for $50 \mathrm{~s}, 53{ }^{\circ} \mathrm{C}$ for $50 \mathrm{~s}$ and $72{ }^{\circ} \mathrm{C}$ for $90 \mathrm{~s}$ with a final extension at $72{ }^{\circ} \mathrm{C}$ for 5 min. DNA templates were initially denatured at $94{ }^{\circ} \mathrm{C}$ for $3 \mathrm{~min}$. Primers for GR were based on published sequences (Miesfeld et al. 1986) and were designed to flank the $\mathrm{N}$-terminal polyglutamine microsatellite producing overall PCR product sizes of $116 \mathrm{bp}$ (MNS) and $113 \mathrm{bp}$ (MHS). Sequences of PCR primers were 5'-AAAGGCTCCACAAGC AATGTG-3' and 5'-GACAGTGAAACGGCTT TGG-3' respectively.

PCR products were resolved on $6 \%$ polyacrylamide sequencing gels (19:1, acrylamide: bisacrylamide) at $50 \mathrm{~W}$ for $3 \mathrm{~h}$ in $1 \times$ TBE buffer $(0.09 \mathrm{M}$ tris-borate buffer with $2 \mathrm{mM}$ EDTA, pH 8.0). GR-specific sequences were identified after blotting onto a positively charged nylon membrane (Pall Biosupport Division, Portsmouth, Hants, UK) and hybridisation with appropriate PCR fragments which had been labelled with ${ }^{32} \mathrm{P}$ using a Random Primer Labelling Kit (Stratagene, La Jolla, CA, USA). Hybridisations were carried out in $10-20 \mathrm{ml}$ sodium phosphate buffer $(0.5 \mathrm{M} \mathrm{pH} \mathrm{7.2)} \mathrm{containing}$ $7 \%$ SDS and $10 \mathrm{mM}$ EDTA for $2-6 \mathrm{~h}$ at $55^{\circ} \mathrm{C}$. Membranes were washed with 100-125 mM sodium phosphate buffer containing $0 \cdot 1 \% \operatorname{SDS}$ at $55{ }^{\circ} \mathrm{C}$ and then autoradiographed.

\section{GR sequencing}

The coding sequence of MHS and MNS GR was determined by RT-PCR methods using total RNA extracted from $100 \mathrm{mg}$ fresh liver tissues with RNAzol (Biogenesis Ltd, Bournemouth, UK) according to the manufacturer's protocol $\mathrm{B}$.

RNA/DNA hybrids used as templates in PCR reactions were generated using MMLV reverse transcriptase (RT) (Stratagene, Cambridge, UK). RNA (5-10 $\mu \mathrm{g})$ was reverse transcribed from a GR 3'UT gene-specific primer, 5'>GTTGAACCA CATGGACTTGG $<3^{\prime}$, under conditions recommended by the supplier of the transcriptase. After $1 \mathrm{~h}$ at $39^{\circ} \mathrm{C}$, reactions were terminated by extraction with phenol/chloroform; aliquots of the supernatant were used for PCR.

PCR primers, based on the sequence of rat GR cDNA (Miesfeld et al. 1986) were designed to produce overlapping templates covering the entire GR coding sequence. Primer pair sequences were as follows:
rGR19-BIO, 5'>BIO-ATGTTTGACAGCTTA GGATCTTGCCAATGG ACTCCA AAGAA $<3$ ' (sense), rGR21, 5'>GTTCAGAGCCCCCAAGG AAGT $<3^{\prime}$ (antisense); rGR31-BIO, 5'>BIO-TTC CTTCTCGAAGGGGACACG (sense), rGR28, 5'> TTGCCAGTTGTGACTGGAGTT<3' (antisense); rGR5-BIO, 5'>BIO-ATTCAGCAAGC CACTGCAGGA $<3^{\prime}$ (sense), rGR2, 5'>CTATAA ACCACATGTACTGCG $<3^{\prime}$ (antisense).

Amplifications were carried out using an Omnigene Thermal Cycler (Hybaid, Basingstoke, Hants, UK) in $25 \mu \mathrm{l}$ reaction volumes by combining $2 \mu \mathrm{l}$ RT product with $20 \mathrm{pmol}$ of each primer and $2 \mathrm{U}$ Taq DNA polymerase (Promega, Southampton, Hants, UK) in a mixture containing $1 \cdot 5-2 \cdot 0 \mathrm{mM}$ $\mathrm{Mg}^{2+}$ (depending on the primer pair) and $0.01 \mathrm{mg} /$ $\mathrm{ml}$ acetylated BSA. Reactions were cycled at $95^{\circ} \mathrm{C}$ for $30 \mathrm{~s}, 60{ }^{\circ} \mathrm{C}$ for $30 \mathrm{~s}$ and $72{ }^{\circ} \mathrm{C}$ for $30 \mathrm{~s}$ for 30 cycles with a final extension at $72{ }^{\circ} \mathrm{C}$ for $5 \mathrm{~min}$. RNA/DNA hybrid templates were initially denatured at $95{ }^{\circ} \mathrm{C}$ for $2 \mathrm{~min}$ prior to the addition of Taq polymerase.

Sequencing of PCR products was carried out directly using Dynabeads (Dynal Ltd, Merseyside, UK). Briefly, purified PCR product $(250-500 \mathrm{ng}$ DNA with 5 -biotin in a volume of $50 \mu \mathrm{l})$ was combined with Dynabeads and immobilised and denatured according to the manufacturer's specifications. Denatured single-stranded templates were sequenced from the reverse primers: $5^{\prime}>\mathrm{GGG}$ GGAGCAAAGTTCAATGAA $<3^{\prime}, 5^{\prime}>$ GGAGCA AAGCAGAGCAGGTT $<3^{\prime}$ and $5^{\prime}>$ TACAAGA CAAATTGATAAGTT $<3^{\prime}$, using the Sequenase kit version 2.0 (Amersham International). Sequencing reactions were run on standard $6 \%$ polyacrylamide $8 \mathrm{M}$ urea gels and exposed to Hyperfilm-MP for $16-18 \mathrm{~h}$ at room temperature.

\section{Blood pressure measurements}

At 3 months of age, under light halothane anaesthesia, a cannula was inserted into the carotid artery of $\mathrm{F}_{2}$ rats and exteriorised at the back of the neck through a subcutaneous tunnel. The animals recovered within $5 \mathrm{~min}$ and $4 \mathrm{~h}$ later the cannulae were connected, without restraint, to a Gould BS 3200 blood pressure recorder. For each rat, average values for systolic and diastolic blood pressures and heart rate were calculated from simultaneous measurements taken at $1 \mathrm{~min}$ intervals over a $1 \mathrm{~h}$ period. The body weight was recorded just before surgery.

\section{Urinary volume and calcium excretion}

Rats were acclimatised to metabolism cages over 2 days; urine was collected for the following $24 \mathrm{~h}$ 


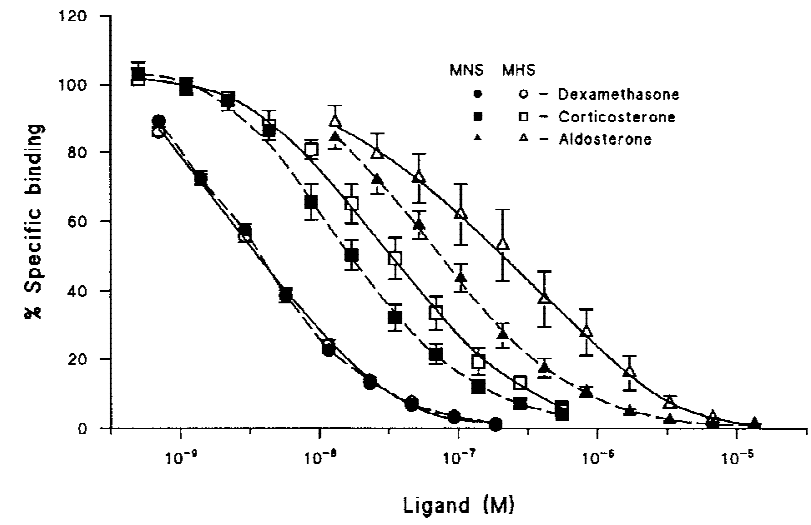

FIGURE 1. Comparison of the effects of competing ligands for specific $\left[{ }^{3} \mathrm{H}\right]$ dexamethasone binding sites in liver cytosol from MHS and MNS rats. Cytosol was equilibrated for $16 \mathrm{~h}$ at $4{ }^{\circ} \mathrm{C}$. Values are means \pm s.E.M., $n=7$.

and the total volume recorded. Urinary calcium concentration was measured by atomic absorption spectrophotometry (Perkin Elmer 1100B), in the presence of $0 \cdot 2 \% \mathrm{LaCl}$; results are expressed as mmol calcium/24 h.

\section{Statistical analysis}

Results are expressed as means \pm standard error of the mean (s.E.M.).

Data from receptor binding studies from MHS and MNS rats were compared using ANOVA for binding capacity and Kruskal-Wallis tests for $K_{\mathrm{d}}$ values; $P$ values of $<0.05$ were considered significant.

Data from cosegregation studies were analysed by one-way ANOVA with Neumann-Keul's correction test for multiple comparisons (SPSS statistical package).

\section{RESULTS}

\section{Competition for dexamethasone binding sites}

All ligands tested in cytosol from both strains of female rat competed for specific $\left[{ }^{3} \mathrm{H}\right]$ dexamethasone binding sites. Ranking, in terms of affinity (dexamethasone $>$ corticosterone $>$ aldosterone) was not different between strains. Competition curves for all three of the ligands are shown in Fig. 1. Both aldosterone and corticosterone appeared to compete less effectively in cytosol from MHS than in that from MNS rats. The competition curves for MNS are similar to those we have reported for other normotensive strains of rat (Panarelli et al. 1995,

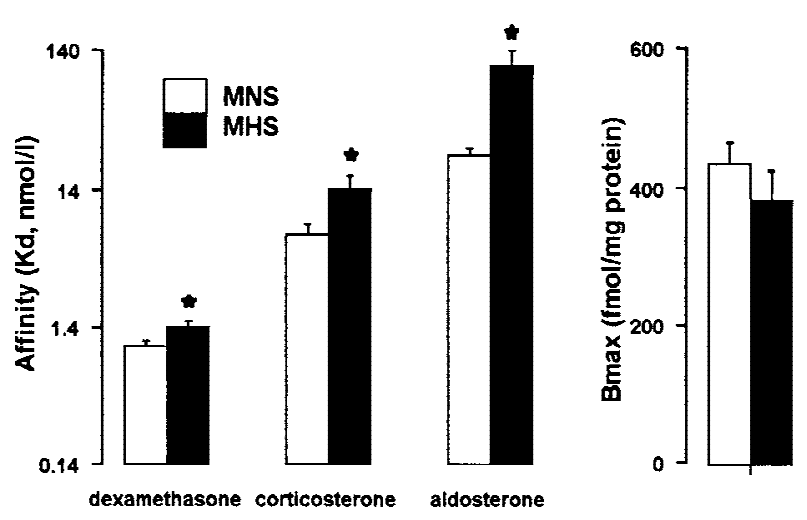

FIGURE 2. Differences between MHS and MNS cytosol in binding affinities of various GR ligands (dissociation constant, left panel) and comparison of GR binding capacities $\left(\mathrm{B}_{\max }\right.$, right panel). Values are means \pm s.E.M., $n=7$.

Soro et al. 1995). Scatchard analysis of dexamethasone binding indicated that, for both MHS and MNS cytosol, the data best fitted a one-site model with $K_{\mathrm{d}}$ and $\mathrm{B}_{\max }$ values of $1 \cdot 39 \pm 0 \cdot 15$ and $1 \cdot 0 \pm 0 \cdot 11 \mathrm{nM}$ and $434 \pm 33$ and $382 \pm 43 \mathrm{fmol} / \mathrm{mg}$ protein respectively. For all ligands, $K_{\mathrm{d}}$ values for MHS were greater than for MNS (Fig. 2). Differences between strains were greatest for the weaker ligands; compared with MNS $K_{\mathrm{d}}$ values, those for MHS were 1.39-, 2.19- and 4.12-fold greater for dexamethasone, corticosterone and aldosterone respectively; in respect of corticosterone this difference of affinity would be of physiological significance. In cytosol from male rats, strain differences in binding properties for dexamethasone were not apparent (Fig. 3) but the difference in affinity between MHS and MNS (6-fold; $P<0 \cdot 05$ ) for corticosterone was similar. Pre-treating cytosol with charcoal extract did not significantly affect steroid binding properties in either strain; a 6 -fold difference between strains in binding affinities for corticosterone $(P<0 \cdot 05$; Fig. 3$)$.

\section{Effects of temperature on dexamethasone binding}

When cytosol, pre-equilibrated overnight with $\left[{ }^{3} \mathrm{H}\right]$ dexamethasone, was incubated at $24{ }^{\circ} \mathrm{C}$, specific binding in buffer containing sodium molybdate remained constant; binding in MNS and MHS cytosol were both unaltered after $3 \mathrm{~h}$ (Fig. 4). When pre-equilibrated cytosol was incubated at $37^{\circ} \mathrm{C}$, specific binding declined rapidly, reaching a minimum after $90 \mathrm{~min}$. The rate and extent of the decrease were not significantly different between strains. To test whether this decline in binding 


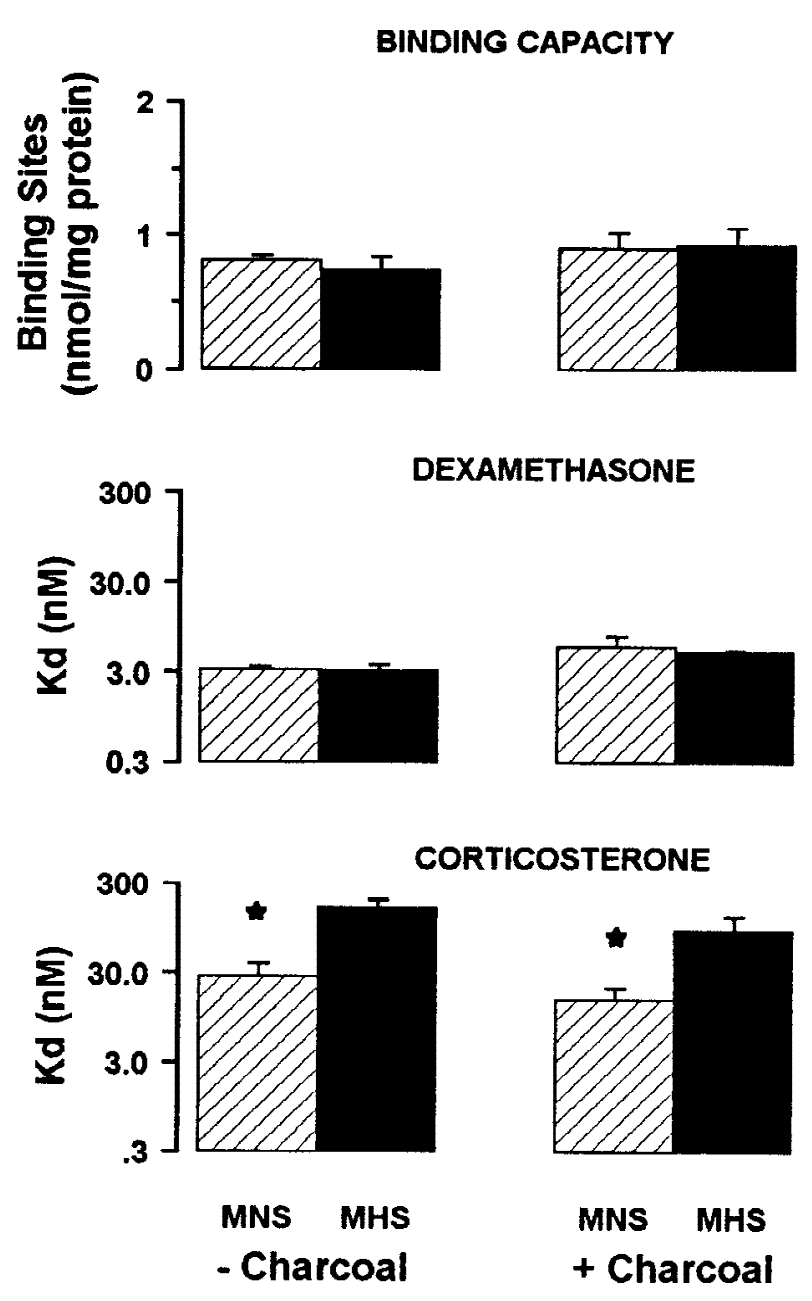

FIGURE 3. Glucocorticoid binding constants in cytosol from male MHS and MNS rats: effects of pre-extraction with charcoal suspension. Values are means \pm s.E.M., $n=4$. $* P<0 \cdot 05$.

reflected a change in affinity and/or receptor concentration, binding characteristics were measured during long-term incubation at this higher temperature. Preliminary time course studies with rat liver cytosol (data not shown) indicated binding of $\left[{ }^{3} \mathrm{H}\right]$ dexamethasone had achieved equilibrium by $30 \mathrm{~min}$. Differences between MHS and MNS binding constants at this time were not statistically significant (Fig. 5). Binding capacities after $30 \mathrm{~min}$ at $37^{\circ} \mathrm{C}$ were similar to those after overnight incubation at $4{ }^{\circ} \mathrm{C}$ but the affinities were less. Figure 5 shows that the decreases in specific binding with prolonged incubation at $37^{\circ} \mathrm{C}$ were due to both a decrease in affinity and a decrease in capacity. After $2 \mathrm{~h}$, capacity of both MHS and MNS cytosol was reduced by more than $50 \%$ and $K_{\mathrm{d}}$ values were 6- to 7 -fold higher. Decreases in

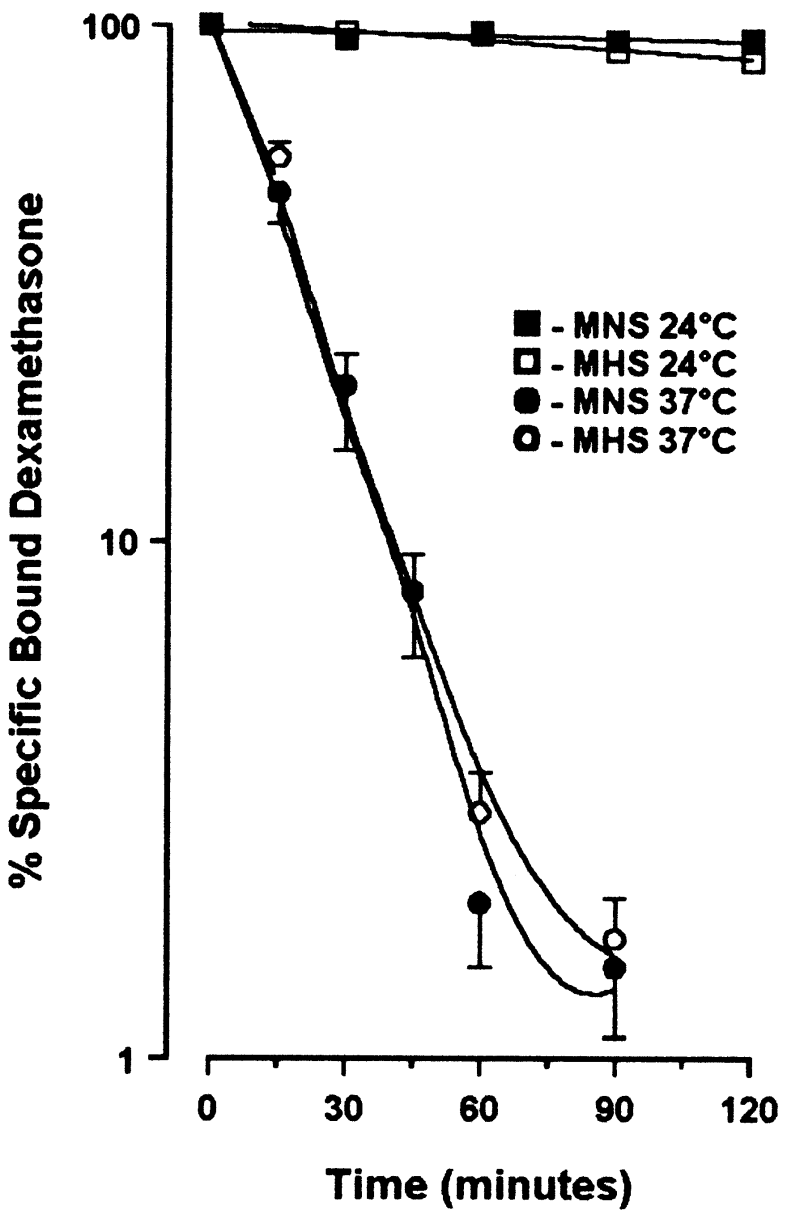

FIGURE 4. Thermostability of specific $\left[{ }^{3} \mathrm{H}\right]$ dexamethasone binding to cytosolic fractions from MHS and MNS livers. After overnight pre-equilibration at $4{ }^{\circ} \mathrm{C}$ with $\left[{ }^{3} \mathrm{H}\right]$ dexamethasone $( \pm 0.5 \mathrm{mM}$ non-radioactive dexamethasone) cytosolic extracts were warmed to $24{ }^{\circ} \mathrm{C}$ or $37^{\circ} \mathrm{C}$. Values are means \pm s.E.M., $n=7$.

capacity could represent denaturation of the receptor although Western blotting studies ( $\mathrm{R} P$ Heeley \& C J Kenyon, unpublished data) indicate that the receptor is stable under these conditions. It is well established that heat shock proteins (HSP) are necessary for high affinity binding of GR ligands (Pratt 1993). Decreased affinity with prolonged incubation at $37^{\circ} \mathrm{C}$ probably represents dissociation of HSP from the receptor complex. There were no significant differences between MHS and MNS in either capacity or affinity at any time point.

\section{GR sequence}

As noted previously (Heeley et al. 1998) the sequence of the cDNA of GR from a rat hepatoma 


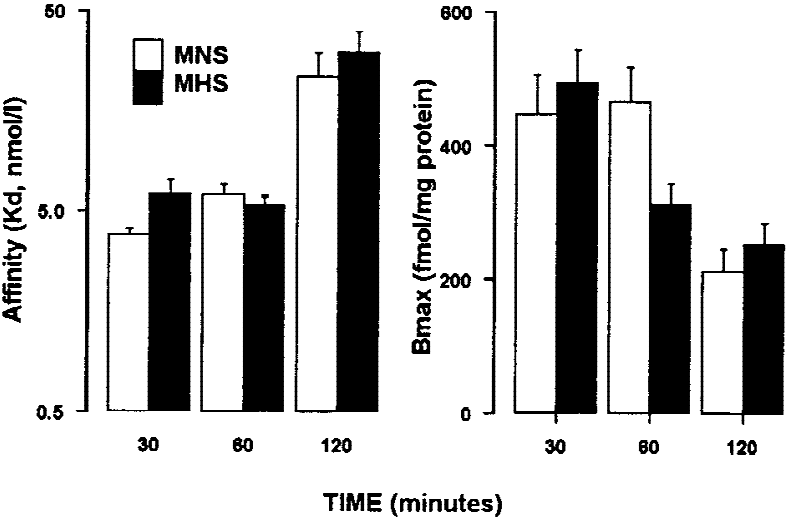

FIGURE 5. The effects of prolonged incubation at $37{ }^{\circ} \mathrm{C}$ on dexamethasone binding constants of cytosol fractions from MHS and MNS liver. Values shown are mean dissociation constants $\left(K_{\mathrm{d}}\right.$, left panel) and binding capacities $\left(\mathrm{B}_{\max }\right.$, right panel $) \pm$ S.E.M., $n=7$.

cell line $(6 \cdot 10.2)$ differed in ten different places from that originally reported by Miesfeld et al. (1986).

The sequence of cDNA of the GR gene from MNS was the same as that of the cDNA clone but the sequence of the GR gene of MHS differed in several respects. The trinucleotide $\mathrm{CAG}$ repeat in exon 2 that encodes the polyglutamine tract contained 20 glutamine codons in MHS and 21 in MNS. The MHS GR gene also showed three silent mutation nucleotides at positions, C198T, C531T and T708C corresponding to Phe66, Phe177 and Asp237 in the modulatory domain of the GR protein.

\section{Associations between GR genotype and phenotypes}

The trinucleotide repeat difference between MHS and MNS was used to genotype $\mathrm{F}_{2}$ progeny of an MHS $\times$ MNS cross. There was no segregation of GR genotype with systolic pressure when the total $\mathrm{F}_{2}$ population was analysed (ANOVA; Table 1). Comparing only homozygous animals, rats of MNS-GR genotype had higher systolic blood pressures than those of MHS genotype (MNS $\times$ MNS $150 \cdot 1 \pm 1.8 \mathrm{mmHg}, n=59$ versus MHS $\times$ MHS $145 \cdot 4 \pm 1 \cdot 3 \mathrm{mmHg}, \quad n=54 ; P=0 \cdot 04)$. There was no significant association between GR genotype and diastolic blood pressure.

Interestingly, when the $\mathrm{F}_{2}$ population was analysed by sex, female $\mathrm{F}_{2}$ progeny, homozygous for the MNS GR allele, had significantly higher systolic blood pressures than either heterozygotes or those homozygous for the MHS allele $(P=0 \cdot 02$; Table 1). The body weight of male, but not female $\mathrm{F}_{2}$ rats, was associated with GR genotype; MNS homozygotes were $11 \%$ heavier than MHS homozygotes $(P<0 \cdot 01)$. In female, but not male $\mathrm{F}_{2}$ progeny, MHS GR homozygotes excreted more calcium than MNS homozygotes; strain differences in calcium metabolism in Milan rats have been described elsewhere (Cirillo et al. 1989). Heart rate and urine volume were not affected by GR genotype (data not shown).

\section{DISCUSSION}

Previous studies of phenotypic differences between MHS and MNS indicated the primacy of renal

TABLE 1. Association of GR genotype with blood pressure, body weight and urinary calcium excretion (mean \pm s.E.M.) in $\mathrm{F}_{2}(\mathrm{MNS} \times \mathrm{MHS})$ rats

\begin{tabular}{|c|c|c|c|c|c|}
\hline & \multirow[b]{2}{*}{ Sex } & \multicolumn{4}{|l|}{ GR genotype } \\
\hline & & MNS $\times$ MNS & MNS $\times$ MHS & MHS $\times$ MHS & $P$ value \\
\hline \multirow[t]{3}{*}{$\begin{array}{l}\text { Systolic blood pressure }(\mathrm{mmHg}) \\
\quad(n)\end{array}$} & Both & $\begin{array}{c}150 \cdot 1 \pm 1 \cdot 8 \\
(59)\end{array}$ & $\begin{array}{c}147 \cdot 7 \pm 1 \cdot 0 \\
(132)\end{array}$ & $\begin{array}{c}145 \cdot 4 \pm 1 \cdot 3 \\
(55)\end{array}$ & NS \\
\hline & Male & $\begin{array}{c}147 \cdot 9 \pm 2 \cdot 7 \\
(22)\end{array}$ & $\begin{array}{c}149 \cdot 1 \pm 1 \cdot 6 \\
(68)\end{array}$ & $\begin{array}{c}146 \cdot 2 \pm 1 \cdot 9 \\
(29)\end{array}$ & NS \\
\hline & Female & $\begin{array}{c}151 \cdot 4 \pm 2 \cdot 4 \\
(37)\end{array}$ & $\begin{array}{c}146 \cdot 3 \pm 1 \cdot 2 \\
(64)\end{array}$ & $\begin{array}{c}144 \cdot 5 \pm 1 \cdot 7 \\
(26)\end{array}$ & $0 \cdot 02$ \\
\hline \multirow[t]{2}{*}{$\begin{array}{l}\text { Body weight }(\mathrm{g}) \\
\qquad(n)\end{array}$} & Male & $\begin{array}{c}439 \pm 11 \\
(21)\end{array}$ & $\begin{array}{c}420 \pm 5 \\
(65)\end{array}$ & $\begin{array}{c}406 \pm 7 \\
(29)\end{array}$ & $<0 \cdot 01$ \\
\hline & Female & $\begin{array}{c}276 \pm 4 \\
\quad(36)\end{array}$ & $\begin{array}{c}276 \pm 3 \\
(63)\end{array}$ & $\begin{array}{c}279 \pm 5 \\
\quad(26)\end{array}$ & NS \\
\hline \multirow[t]{2}{*}{$\begin{array}{l}\text { Urinary calcium (mmol/day) } \\
\qquad(n)\end{array}$} & Male & $\begin{array}{l}29 \cdot 6 \pm 4 \cdot 8 \\
\quad(21)\end{array}$ & $\begin{array}{c}24 \cdot 0 \pm 2 \cdot 2 \\
\quad(59)\end{array}$ & $\begin{array}{l}31 \cdot 4 \pm 3 \cdot 8 \\
\quad(25)\end{array}$ & NS \\
\hline & Female & $\begin{array}{c}55 \cdot 6 \pm 7 \cdot 6 \\
\quad(35)\end{array}$ & $\begin{array}{c}63 \cdot 8 \pm 6 \cdot 0 \\
\quad(63)\end{array}$ & $\begin{array}{l}89 \cdot 7 \pm 8 \cdot 9 \\
\quad(24)\end{array}$ & $<0 \cdot 005$ \\
\hline
\end{tabular}


function in the control of blood pressure (Baer \& Bianchi 1978, Bianchi \& Ferrari 1983, Persson et al. 1985). Point mutations in the genes encoding a membrane skeleton protein, adducin, were identified, which appear to explain part of the difference in blood pressure between MHS and MNS (Bianchi et al. 1994). The possibility that an abnormality of GR function could account for the remaining difference in blood pressure and/or provide the genetic basis for other phenotypic differences between MNS and MHS is the subject of the present investigations.

Here we demonstrate: (i) evidence of impaired GR function in MHS liver cytosol; (ii) sequence differences in the genes encoding GR; and (iii) cosegregation of GR genotype with systolic pressure and body weight. These observations are discussed below.

Increased adrenocortical activity with hypertrophy of the adrenal cortex, increased secretory activity and raised plasma corticosterone concentrations have been identified in MHS compared with MNS (Mantero et al. 1983, Ferrari et al. 1985, Stewart et al. 1993, Fraser et al. 1994). Normally, feedback inhibition by corticosterone of pituitary adrenocorticotrophin (ACTH) secretion would be expected to correct overactivity of the cortex. However, if GR function is impaired, then higher than normal concentrations of corticosterone are required to maintain homeostasis. Thus in rodents and primates, naturally occurring or genetically engineered differences in receptor function are associated with abnormal patterns of hormone secretion (Mantero et al. 1983, Brandon et al. 1991, Hurley et al. 1991, Cole et al. 1993, Stewart et al. 1993, Keightley \& Fuller 1994). We compared both ligand specificity and thermolability of GR, as well as binding capacity, in hepatic cytosol of MNS and MHS. Binding capacities were similar but affinities for dexamethasone, corticosterone and aldosterone were lower in MHS than MNS liver cytosol. The differences in affinity were least for the strongest ligand (dexamethasone) and greatest for the weakest ligand (aldosterone). It seems unlikely that the presence of endogenous steroids could account for differences in specificity since the difference remained after pre-extraction of cytosol with charcoal to remove endogenous steroids. Specificity and sensitivity of glucocorticoid hormone actions are controlled by a variety of factors including: (i) access of hormone to receptor, which is regulated by enzymes and by cell membrane steroid hormone transporters; (ii) a number of secondary proteins and other factors which, when complexed with the receptor, maintain a high affinity binding state and facilitate translocation to the nucleus or interaction with glucocorticoid response elements on DNA; (iii) tissue-specific receptor expression; and (iv) the primary structure of the receptor protein. Most of these factors can be excluded as likely explanations of the present observations.

Lower hepatic 11ß-hydroxysteroid-dehydrogenase (11ßHSD) activity has been observed in MHS compared with MNS (Stewart et al. 1993). The liver isoform of $11 \beta$ HSD (type 1 ) favours the reduction of 11-dehydrocorticosterone (biologically inactive) to produce corticosterone (Jamieson et al. $1995)$. Reduced $11 \beta$ HSD in MHS liver would therefore limit access of corticosterone to receptor. However, reduced $11 \beta \mathrm{HSD}$ activity is unlikely to be a cause of impaired receptor binding in MHS for two reasons. First, $11 \beta \mathrm{HSD}$ is a microsomal enzyme which would not be active in the cytosolic extracts used here, particularly in the absence of added cofactors. Secondly, the ranking of the differences in affinity between MHS and MNS for the ligands tested (aldosterone $>$ corticosterone> dexamethasone) does not match substrate specificity for $11 \beta \mathrm{HSD}$. For similar reasons, the involvement of plasma membrane steroid hormone transporters in the regulation of receptor binding in cytosol is unlikely. Previous studies (Stewart et al. 1993) and present observations of binding capacity do not indicate strain differences in tissue-specific expression of GR.

A common observation in clinical studies of steroid hormone resistance is that receptor binding is thermolabile (Werner et al. 1992). In these cases, affinity of the receptor is markedly decreased by prolonged incubation at high temperatures. This effect is probably due to dissociation of the receptor from HSP; high affinity binding is only observed when the receptor is complexed with other proteins including hsp90 and hsp70 (Pratt 1993). For example we have previously observed greater thermostability of the receptor from spontaneously hypertensive (SHR) compared with normotensive Wistar Kyoto (WKY) rats (Panarelli et al. 1995). In the present study, no such difference between MHS and MNS receptors has been observed.

The MHS GR cDNA sequence differs in four respects from that of MNS cDNA. There are three point mutations which are silent and therefore unlikely to be of phenotypic importance. The fourth difference concerns a trinucleotide $(\mathrm{CAG})$ repeat region in exon 2 which encodes a polymeric glutamine region close to the $\mathrm{N}$ terminus of the GR. We have shown that this region is highly variable in wild and inbred strains of laboratory rats with CAG repeat lengths varying from 7 to 23; the MHS GR gene has one CAG repeat less (20) than the MNS gene (21). When expressed in CV-1 cells, full length 
GR cDNAs with either 20 or 21 CAG repeats resulted in GR proteins which showed no difference in binding affinity for dexamethasone or corticosterone (Heeley et al. 1998). In some respects the MHS rat is similar to the New World primates, which generally show evidence of glucocorticoid resistance in vivo; white blood cells of the Squirrel monkey show impaired steroid receptor binding properties. However, cloned GR from this species shows no difference in binding properties when compared with cloned human GR despite evidence of several differences in gene sequence (Reynolds et al. 1997).

Mutations in the $\mathrm{N}$-terminal region of steroid hormone receptors affect other receptor properties. For example, changing the amino acid sequence of rat GR from polyglutamine to a polyalanine region renders the receptor incapable of transactivation (Lanz et al. 1995). In vivo studies have also demonstrated that polymeric regions of genes are of functional importance in various diseases (Han et al. 1994). In Kennedy's disease, for example, a CAG repeat region in the gene encoding the androgen receptor (AR), a member of the superfamily of steroid/thyroid hormone receptors, is greatly expanded. This polyglutamine tract in AR, which is homologous with that in rat GR, causes androgen insensitivity in patients with Kennedy's disease due, in part, to subnormal transactivation and possibly also to reduced affinity for endogenous steroid hormones (Warner et al. 1992, Mhatre et al. 1993).

The presence of a microsatellite polymorphism in the GR gene of Milan rats represents a useful marker for analysing blood pressure and other phenotypes in cosegregation studies. GR genotype cosegregated with three variables, blood pressure, calcium excretion and body weight. The association of GR genotype with body weight might indicate a quantitative trait locus on chromosome 18. In $\mathrm{SHR} \times \mathrm{WKY} \quad \mathrm{F}_{2}$ hybrids a gap junction protein locus on chromosome 18 has also been shown to cosegregate with body weight (Katsuya et al. 1995). Further studies with close flanking markers are required to show that the maximum effect is determined by GR polymorphism.

As has been described in patients with primary cortisol resistance (Lamberts et al. 1992, Arai \& Chrousos 1994), an impaired GR might cause an increase in blood pressure secondary to raised plasma corticosterone concentrations acting on mineralocorticoid receptors. Given that MHS exhibit signs of excess mineralocorticoid activity (Fraser et al. 1994), our preliminary hypothesis was that MHS represented a similar genetic mutation of GR. Counter to our expectations, MHS GR genes were associated with lower not higher blood pressure. Although this observation effectively excludes a role for GR in the aetiology of hypertension in MHS, questions remain as to whether and how the GR locus is a determinant of blood pressure and why females and not males are affected.

As with all association studies, the possibility that the GR locus is in linkage disequilibrium with another gene unrelated to GR function cannot be dismissed. Alternatively, given that glucocorticoid hormones affect blood pressure by a mineralocorticoid-independent mechanism (Tonolo et al. 1988), GR impairment could affect blood pressure more directly. A subtle impairment of GR properties, insufficient to raise plasma corticosterone levels beyond the capacity where mineralocorticoid receptors are protected from endogenous glucocorticoid hormones, might nevertheless reduce net glucocorticoid hormone and hence lower blood pressure. Against this hypothesis is evidence that GR impairment, at least in parental strains, is corrected through reduced feedback control of the hypothalamopituitary-adrenal axis. As discussed above, however, mutations in homologous regions of other steroid receptors affect transactivation as well as binding functions. Recent studies have suggested that interactions of GR transactivation domains with secondary proteins and other non-GR transcription factors can influence GR properties in a tissue-specific manner (Chrousos et al. 1993, Adcock et al. 1995, De Lange et al. 1997). The mechanisms of glucocorticoid-induced hypertension and relevant target tissues are not precisely known (Kenyon \& Morton 1994). Altered GR interaction with other proteins may account for blood pressure and other phenotypes associated with MHS GR genes.

Phenotypic associations with MHS GR alleles differ in male and female rats; body weight is affected in males whereas variations of urinary calcium excretion and low blood pressure are traits which are more obvious in females. In clinical cases, sex-dependent variations in manifestations of primary glucocorticoid resistance are thought to be a consequence of increased adrenal androgen synthesis due to raised plasma ACTH (Arai \& Chrousos 1994). In rats, however, adrenal androgen production is not as great and female sex steroid hormones are perhaps more important. Circulating levels of corticosterone, ACTH and corticosteronebinding globulin and responses to stress are markedly higher in female rats (McCormick et al. 1995). It is significant that female rats assume more male-like glucocorticoid-dependent variables after ovariectomy with lower corticosterone-binding globulin, altered steroid metabolism, lower plasma corticosterone, reduced adrenal weight and increased thymus and body weight (C J Kenyon, 
J Noble, A E King \& J Melville, unpublished observations). It follows that expression of impaired GR characteristics may also be differentially influenced by sex hormones which, in turn, could account for gender differences in the present association study.

In conclusion, we have sequenced the GR gene in MHS and MNS rats and demonstrated a polymorphism in a polyglutamine tract of the coding region of exon 2. Compared with MNS, MHS have impaired GR function such that the endogenous ligand, corticosterone, is bound with less affinity in hepatic cytosol fractions. It is not known whether GR polymorphism affects transactivation properties of the receptor. Cosegregation studies in a cross between MHS and MNS rats indicated that GR polymorphism is associated with differences in a number of phenotypes including systolic blood pressure. Further studies are needed to establish whether differences in the GR gene cause phenotypic differences or whether genes, in close linkage disequilibrium with the GR locus, are involved.

\section{ACKNOWLEDGEMENTS}

This work was funded by the Medical Research Council (UK). M P received fellowships from the Society for Endocrinology (UK) and the British Hypertension Society. We thank Dr R Miesfeld for kindly providing us with cDNA from a rat hepatoma cell line $(6 \cdot 10.2)$. We are grateful too for the technical assistance of Mrs Liliana Duzzi and Mrs Elena Minotti and for advice on statistical analysis from Dr Niall Anderson.

\section{REFERENCES}

Adcock IM, Lane SJ, Brown CR, Lee TH \& Barnes PJ 1995 Abnormal glucocorticoid receptor-activator protein 1 interaction in steroid-resistant asthma. Fournal of Experimental Medicine 182 1951-1958.

Arai K \& Chrousos GP 1994 Glucocorticoid resistance. In Bailliere's Clinical Endocrinology and Metabolism (Hormones, Receptors and Enzymes) vol 8:2, pp 317-331. Eds MC Sheppard \& P Stewart. London: Bailliere Tindall.

Baer PG \& Bianchi G 1978 Renal micropuncture study of normotensive and Milan hypertensive rats before and after development of hypertension. Kidney International 13 452-466.

Bianchi G \& Ferrari P 1983 Animal models for arterial hypertension. In Hypertension, pp 534-554. Eds J Genest, O Kuchel, P Hamet \& M Cantin. New York: McGraw-Hill.

Bianchi G, Ferrari P \& Barber BR 1984 The Milan hypertensive strain. In Handbook of Hypertension, vol 4, pp 328-349. Ed. W de Jong. Amsterdam: Elsevier.

Bianchi G, Ferrari P, Salvati P, Parenti P, Cusi D \& Guidi E 1986 A renal abnormality in the Milan hypertensive strain of rats and in humans predisposed to essential hypertension. Fournal of Hypertension 4 (Suppl 3) S33-S36.
Bianchi G, Tripodi G, Casari G, Salardi S, Barber BR, Garcia R, Leoni P, Torielli L, Cusi D, Ferrandi M, Pinna LA, Baralle FE \& Ferrari P 1994 Two point mutations within the adducin genes are involved in blood pressure. Proceedings of the National Academy of Sciences of the USA 91 3999-4003.

Brandon DD, Markwick AJ, Flores M, Dixon K, Albertson BD \& Loriaux DL 1991 Genetic variation of the glucocorticoid receptor from a steroid-resistant primate. Fournal of Molecular Endocrinology 7 89-96.

Chrousos GP, Detera-Wadleigh SD \& Karl M 1993 Syndromes of glucocorticoid resistance. Annals of Internal Medicine 119 1113-1124.

Cirillo M, Galetti F, Strazullo P, Torielli L \& Melloni MC 1989 On the pathogenic mechanism of hypercalciuria in genetically hypertensive rats of the Milan strain. American Fournal of Hypertension 2 741-746.

Cole TJ, Blendy JA, Schmid W, Ströhle U \& Schütz G 1993 Expression of the mouse glucocorticoid receptor and its role during development. Fournal of Steroid Biochemistry and Molecular Biology 47 49-53.

De Lange P, Koper JW, Huizenga NATM, Brinkmann AO, De Jong FH, Karl M, Chrousos GP \& Lamberts SWJ 1997 Differential hormone-dependent transcriptional activation and repression by naturally occurring human glucocorticoid receptor variants. Molecular Endocrinology 11 1156-1164.

Ferrari P, Mantero F \& Bianchi G 1985 Role of adrenal steroids in the rat genetic models of hypertension. In The Adrenal Gland and Hypertension. Serono Symposia Publications from Raven Press, vol 27, pp 149-158. Eds F Mantero, EG Biglieri, JW Funder \& BA Scoggins. New York: Raven Press.

Fraser R, Ancil AK, Brown WB, Ingram MC, Holloway CD, Henderson IW \& Kenyon CJ 1994 Evidence of abnormalities in corticosteroid secretion leading to volume-dependent hypertension in Milan rats. Hypertension 24 512-515.

Han J, Hsu C, Zhu Z, Longshore JW \& Finley WH 1994 Over-representation of the disease associated (CAG) and (CGG) repeats in the human genome. Nucleic Acids Research 22 1735-1740.

Heeley RP, Gill E, van Zutphen B, Kenyon CJ \& Sutcliffe RG 1998 Polymorphisms of the glucocorticoid receptor gene in laboratory and wild rats: steroid binding properties of trinucleotide CAG repeat length variants. Mammalian Genome 9 198-203.

Hurley DM, Accili D, Stratakis CA, Karl M, Vamvakopoulos N, Rorer E, Constantine K, Taylor SI \& Chrousos GP 1991 Point mutation causing a single amino acid substitution in the hormone binding domain of the glucocorticoid receptor in familial glucocorticoid resistance. Fournal of Clinical Investigation 87 680-686.

Jamieson PM, Chapman KE, Edwards CRW \& Seckl JR 1995 $11 \beta$-Hydroxysteroid dehydrogenase is an exclusive $11 \beta$-reductase in primary cultures of rat hepatocytes: effect of physicochemical and hormonal manipulations. Endocrinology 136 4754-4761.

Katsuya T, Takami S, Higaki J, Serikawa T, Mikami H. Miki T \& Ogihara T 1995 Gap junction protein locus on chromosome 18 cosegregates with body weight in the spontaneously hypertensive rat. Clinical and Experimental Hypertension Research 18 63-67.

Keightley M-C \& Fuller PJ 1994 Unique sequences in the guinea pig glucocorticoid receptor induce constitutive transactivation and decrease steroid sensitivity. Molecular Endocrinology 8 431-439.

Kenyon CJ \& Morton JJ 1994 Experimental steroid-induced hypertension. In Textbook of Hypertension, pp 494-500. Ed. JD Swales. Oxford: Blackwell Scientific Publications. 
Laird PW, Zijderveld A, Linders K, Rudnicki MA, Jaenisch R \& Berns A 1991 Simplified mammalian DNA isolation procedure. Nucleic Acids Research 194293.

Lamberts SWJ, Koper JW, Biemond P, den Holder FH \& de Jong FH 1992 Cortisol receptor resistance: the variability of its clinical presentation and response to treatment. Fournal of Clinical Endocrinology and Metabolism 74 313-321.

Lanz RB, Wieland S, Hug M \& Rusconi S 1995 A transcriptional repressor obtained by alternative translation of a trinucleotide repeat. Nucleic Acids Research 23 138-145.

Lowry OH, Rosenbrough NJ, Farr AL \& Randall RJ 1951 Protein measurement with the folin phenol reagent. Fournal of Biological Chemistry 193 265-275.

McCormick CM, Smythe JW, Sharma S \& Meaney MJ 1995 Sex-specific effects of prenatal stress on hypothalamicpituitary-adrenal responses to stress and brain glucocorticoid receptor density in adult rats. Developmental Brain Research 84 55-61.

Mantero F, Nussdorfer GG, Robba C, Opocher G, Ferrari P \& Bianchi G 1983 Evidence for mineralocorticoid hyperactivity in the Milan hypertensive strain of rat. Fournal of Hypertension 1 (Suppl 2) 150-152.

Mhatre AN, Trifiro MA, Kaufman M, Kazemi-Esfarjani P, Figlewski D, Rouleau G \& Pinsky L 1993 Reduced transcriptional regulatory competence of the androgen receptor in X-linked spinal and bulbar muscular atrophy. Nature Genetics 5 184-188.

Miesfeld R, Rusconi S, Godowski PJ, Maler BA, Wilkstrom AC, Gustafsson J-A \& Yamamoto KR 1986 Genetic complementation of a glucocorticoid receptor deficiency by expression of cloned receptor cDNA. Cell 46 389-399.

Panarelli M, Holloway CD, Barr ABP, Fraser R \& Kenyon CJ 1995 Differences in temperature-sensitive receptor binding of glucocorticoid in spontaneously hypertensive (SHR) and normotensive Wistar Kyoto (WKY) rats. Steroids 60 73-75.

Persson AEG, Bianchi G \& Boberg U 1985 Tubuloglomerular feedback in hypertensive rats of the Milan strain. Acta Physiologica Scandinavica 123 139-146.
Pratt WB 1993 The role of heat shock proteins in regulating the function, folding, and trafficking of the glucocorticoid receptor. Fournal of Biological Chemistry 268 21455-21458.

Reynolds PD, Pittler SJ \& Scammell J 1997 Cloning and expression of the glucocorticoid receptor from the squirrel monkey (Saimiri boliviensis boliviensis), a glucocorticoid resistant primate. Fournal of Clinical Endocrinology and Metabolism 82 465-472.

Soro A, Panarelli M, Holloway CD, Fraser R \& Kenyon CJ 1995 Effect of the glucocorticoid antagonist RU 486 in spontaneously hypertensive and Sprague Dawley rats. Fournal of Endocrinological Investigation 18 833-839.

Stewart PM, Whorwood CB, Valentino R, Burt D, Sheppard MC \& Edwards CRW 1993 11 $\beta$-Hydroxysteroid dehydrogenase activity and gene expression in the hypertensive Bianchi-Milan rat. Fournal of Hypertension 11 349-354

Tonolo G, Fraser R, Connell JMC \& Kenyon CJ 1988 Chronic low-dose infusion of dexamethasone in rats: effects on blood pressure, body weight and plasma atrial natriuretic peptide. Fournal of Hypertension 6 25-31.

Tripodi G, Valtorta F, Torielli L, Chieregatti E, Salardi S, Trusolino L, Menegon A, Ferrari P, Marchisio PC \& Bianchi G 1996 Hypertension associated point mutations in the adducin $\alpha$ and $\beta$ subunits affect actin cytoskeleton and ion transport. Fournal of Clinical Investigation 97 2815-2822.

Warner CL, Griffin JE, Wilson JD, Jacobs LD, Murray KR, Fishbeck KH, Dickoff D \& Griggs RC 1992 X-linked spinomuscular atrophy: a kindred with associated abnormal androgen receptor binding. Neurology 42 2181-2184.

Werner S, Thoren M, Gustafsson J-A \& Brönnegörd M 1992 Glucocorticoid receptor abnormalities in patients with idiopathic resistance to dexamethasone diagnosed when evaluated for adrenocortical disorders. Fournal of Clinical Endocrinology and Metabolism 75 1005-1009.

REVISED MANUSCRIPT RECEIVED 19 December 1997 